\title{
Enamel carbon isotope evidence of diet and habitat of Gigantopithecus blacki and associated mammalian megafauna in the Early Pleistocene of South China
}

\author{
ZHAO LingXia ${ }^{1,2,4^{*}}$, ZHANG LiZhao $^{1,2}$, ZHANG FuSong $^{3} \&$ WU XinZhi ${ }^{2}$ \\ ${ }^{1}$ Key Laboratory of Evolutionary Systematics of Vertebrates, Institute of Vertebrate Paleontology and Paleoanthropology, Chinese Academy of \\ Sciences, Beijing 100044, China; \\ ${ }^{2}$ Laboratory of Human Evolution, Institute of Vertebrate Paleontology and Paleoanthropology, Chinese Academy of Sciences, Beijing 100044, \\ China; \\ ${ }^{3}$ State Key Laboratory of Lithospheric Evolution, Institute of Geology and Geophysics, Chinese Academy of Sciences, Beijing 100029, China; \\ ${ }^{4}$ State Key Laboratory of Palaeobiology and Stratigraphy, Nanjing Institute of Geology and Paleontology, Chinese Academy of Sciences, \\ Nanjing 210008, China
}

Received May 11, 2011; accepted July 29, 2011; published online September 12, 2011

\begin{abstract}
Enamel stable carbon isotope analyses were conducted on the large fossil ape Gigantopithecus blacki and an associated mammalian megafauna from Longgudong Cave in Jianshi and Juyuandong Cave in Liucheng, South China. The range in $\delta^{13} \mathrm{C}$ values $\left(-18.8 \%\right.$ o to $-14.1 \%$ ) indicates that $G$. blacki and other large mammals fed on solely $\mathrm{C}_{3}$ biomass, and lived in forest habitats, and not open country or savannas. These results are consistent with other faunal and floral analyses for that time. The diet and habitat of G. blacki were significantly different from those of early hominins (Australopithecus and Paranthropus) from South and East Africa. Extinction of G. blacki probably was a result of forest habitat fragmentation and deterioration.
\end{abstract}

Gigantopithecus blacki, diet, enamel stable carbon isotopes, habitat

Citation: Zhao L X, Zhang L Z, Zhang F S, et al. Enamel carbon isotope evidence of diet and habitat of Gigantopithecus blacki and associated mammalian megafauna in the Early Pleistocene of South China. Chinese Sci Bull, 2011, 56: 3590-3595, doi: 10.1007/s11434-011-4732-4

Gigantopithecus blacki was a species of large hominoids that dominated the Pleistocene of South China (Figure 1). The characteristics of this species include a large mandible and massive buccal teeth with very thick enamel, and some features similar to hominins [1-4]. Information regarding its diet and habitat requirements is of interest to both paleoanthropologists and the general public.

Based on the associated fauna, most scholars believe that G. blacki lived in subtropical forest environments [5-7]. However, open-country grasslands also have been hypothesized to have been used by Gigantopithecus bilaspurensis of North India and G. blacki of South China. Pilbeam suggested that it is most likely that Gigantopithecus species spent most of their time on the ground, foraging for their

*Corresponding author (email: zhaolingxia@ivpp.ac.cn) food in open country, similar to the gelada baboon in Ethiopia today [8]. The massive mandible, large postcanine teeth and thick enamel characteristics resemble the powerful mastication evident among Gigantopithecus, Paranthropus and Australopithecus, and may imply a similar diet and habitat use. However, the precise habitat of Gigantopithecus is still unknown.

Analysis of stable carbon isotopes is a powerful method [9-11] for exploring the diet and habitat use of extinct herbivorous mammals, including early hominins in South and East Africa [12-21]. This method is based on the fact that the carbon isotope composition is significantly different between plants that use different photosynthetic pathways, such as $\mathrm{C}_{3}$ plants $\left(\delta^{13} \mathrm{C}\right.$ from $-22 \%$ o to $-35 \%$ o) and $\mathrm{C}_{4}$ plants (from $-8 \%$ o to $-16 \%$ ). Furthermore, the stable carbon isotope composition of enamel is dependent on the diet 


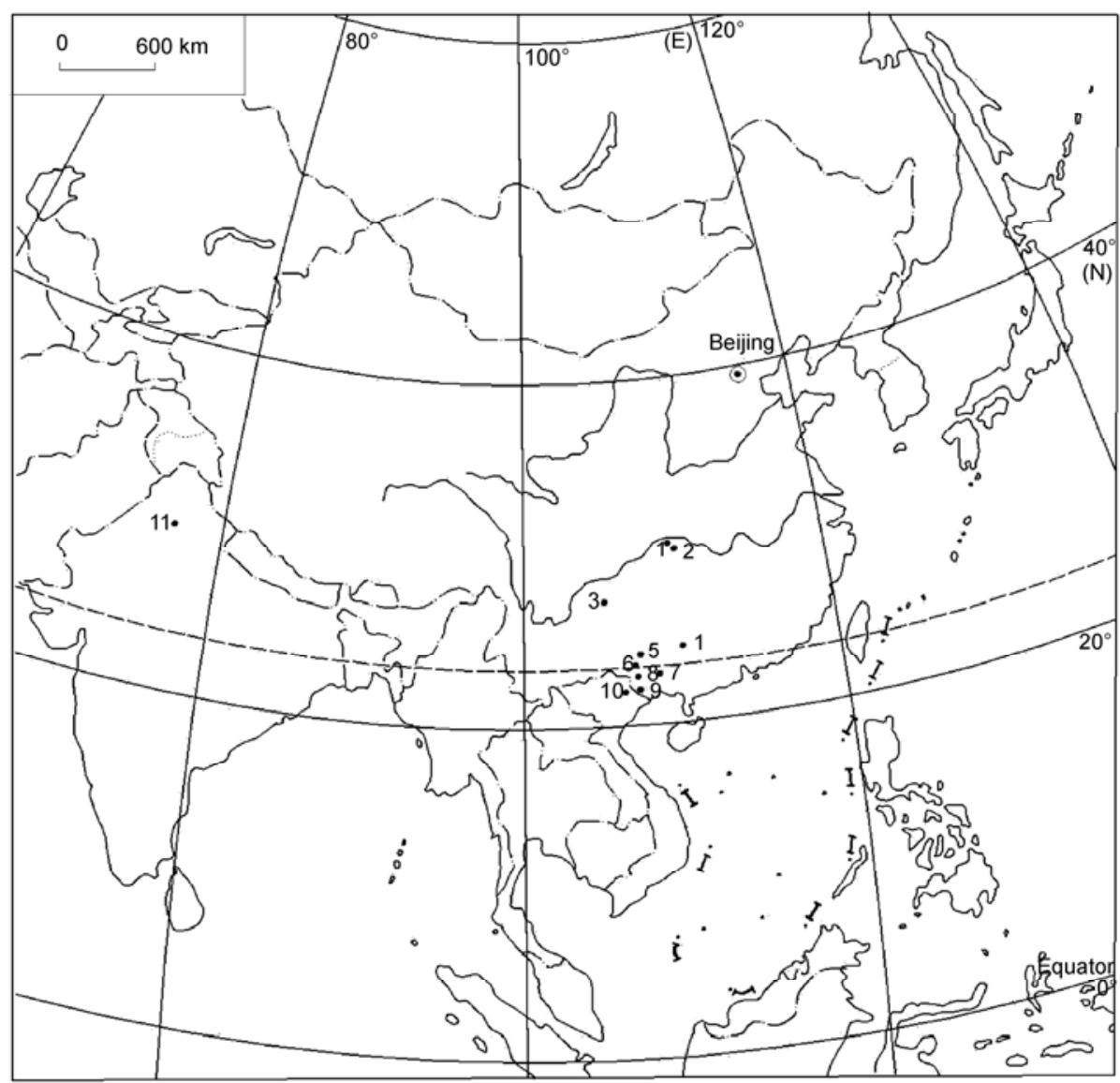

Figure 1 Fossil sites of G. blacki (1-10) and G. bilaspurensis (11). 1, Longgupo of Wushan; 2, Longgudong of Jianshi; 3, Baeryan of Bijie; 4, Juyuandong of Liucheng; 5, Nongmoshan of Bama; 6, Mohuidong of Bubing; 7, Lalishan of Wuming; 8, Heidong of Daxin; 9, Sanhedadong of Chongzuo; 10, Than Khuyen in northern Vietnam; 11, Haritalyangar in northern India.

components throughout the food chain. In this paper, we analyze enamel stable carbon isotope values, diets and habitat use of $G$. blacki and the associated mammalian megafauna from two sites in South China.

\section{Materials and methods}

Longgudong Cave $\left(30^{\circ} 40^{\prime} \mathrm{N}, 110^{\circ} 05^{\prime} \mathrm{E}\right.$, altitude $\left.740 \mathrm{~m}\right)$ of Jianshi in Hubei Province is an early Pleistocene hominin site, from where more than 100 teeth of Gigantopithecus and 6 teeth of hominins have been identified as Australopithecine [22] or Meganthropus [7]. Dating of the associated fauna and paleomagnetic dating have placed the geological age of these teeth findings as Early Pleistocene. The geological age of Juyuandong Cave $\left(24^{\circ} 40^{\prime} \mathrm{N}, 109^{\circ} 15^{\prime} \mathrm{E}\right.$, altitude $200 \mathrm{~m}$ ) of Liucheng in Guangxi also is Early Pleistocene, but earlier than that of the Longgudong site, where 3 mandibles and about 1000 teeth of Gigantopithecus have been discovered.

A total of 32 tooth samples were investigated in the present study. Four teeth of G. blacki and 24 teeth of associated large mammals were analyzed from Longgudong Cave,
Jianshi. The other 4 teeth of $G$. blacki were taken from Jvyuandong Cave of Liucheng (Figure 1). The large mammals included 9 species: Sus sp., Leptobos sp., Cervus sp., Equus sp., Rhinoceros sinensis, Tapirus sinensis, Pachycrocuta licenti, Ursus sp., Ailuropoda wulingshanensis (Table 1).

The clean enamel fragments were ground into powder. The powder was allowed to react in 5\% sodium hypochlorite overnight to eliminate bacterial protein and humates, and then in $6 \%$ acetic acid overnight to remove diagenetic carbonates. Clean and dry $\mathrm{CO}_{2}$ was produced by reaction of enamel samples in $100 \%$ phosphoric acid hydrolysis. Carbon isotopes were measured on a Finnigan Mat252 mass spectrometer at the Stable Isotope Laboratory in the State Key Laboratory of Lithospheric Evolution of Institute of Geology and Geophysics, Chinese Academy of Sciences, Beijing, China. The analytical precision of the $\delta^{13} \mathrm{C}$ values (PDB) was better than $0.1 \%$.

\section{Results and discussion}

\subsection{Enamel $\delta^{13} \mathrm{C}$ values and diet}

A total of 32 enamel powder samples from 32 individual 
teeth were prepared. A total of 42 enamel powder samples were analyzed for stable carbon isotopes $\left(\delta^{13} \mathrm{C}\right)$, of which 2-3 parallel samples were taken for 9 tooth samples (Table $1)$. The most enriched $\delta^{13} \mathrm{C}$ value was $-14.1 \%$, and the most depleted was $-18.8 \%$. An enrichment of $14 \%$ for $\delta^{13} \mathrm{C}$ was observed between food types and enamel [23]. The $\delta^{13} \mathrm{C}$ values of food sources should be from $-32.8 \%$ to
$-28.1 \%$, which is within the $\delta^{13} \mathrm{C}$ range of $\mathrm{C}_{3}$ biomass and far too negative for that of $\mathrm{C}_{4}$ biomass. It is clear that $\mathrm{Gi}$ gantopithecus and the affiliated megafauna (e.g. browsers (Cervus sp. and Tapirus sinensis), grazers (Equus sp. and Leptobos sp.) and carnivores (Pachycrocuta licenti and Ursus sp.)) all derived their carbon from solely $\mathrm{C}_{3}$ biomass sources.

Table 1 Enamel stable carbon isotope ratios ( $\delta^{13} \mathrm{C}$ in PDB) of Gigantopithecus blacki and an associated large mammalian fauna

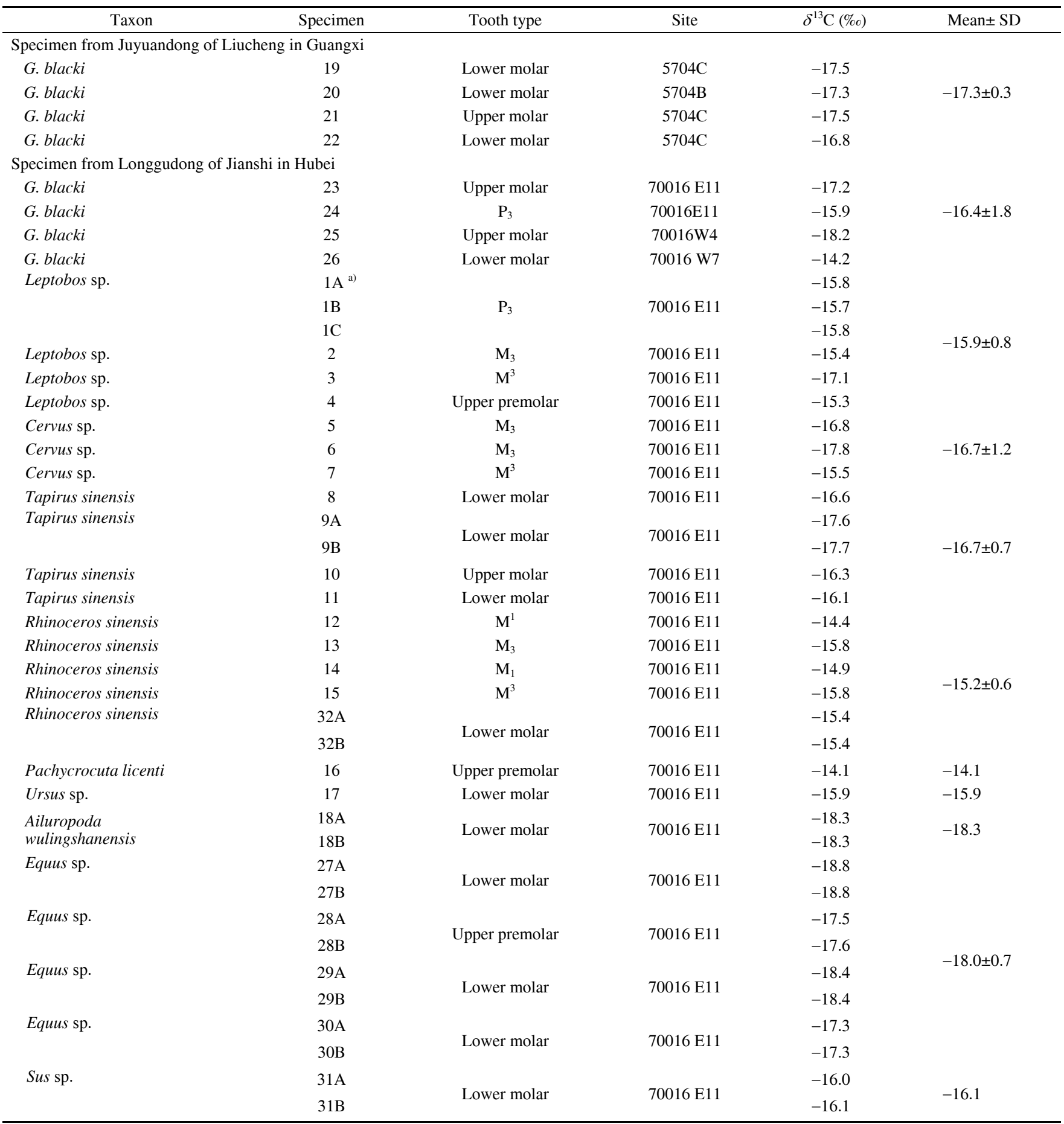

a) A, B and C under the same number represent parallel powder samples from the same tooth. 


\subsection{Diet and habitat}

Results indicate that the living environment of $G$. blacki and the associated mammalian megafauna was vegetation dominated by $\mathrm{C}_{3}$ plants from a dense forest or possibly an open savanna environment in a cold or cool climate.

$\mathrm{C}_{4}$ plants were commonly distributed in the subtropical region of South China [24]. The Three Gorges region of Yangtze River, where the Jianshi site is located, is mainly covered by subtropical forest flora today. In this region, $\mathrm{C}_{4}$ photosynthesis species constitute only about $2.5 \%$ of the total 2685 vascular plant species, and Gramineae are the leading $\mathrm{C}_{4}$ species and constitute about $36 \%$ of the total grasses. $95 \% \mathrm{C}_{4}$ species can be found at 500-800 m altitude [25]. Surveys of a subtropical monsoon evergreen broadleafed forest in South China have shown that $\mathrm{C}_{4}$ plants survive only in open ground areas, and cannot be found in dense forests [26]. If Gigantopithecus lived in an open environment at the Jianshi site, where $\mathrm{C}_{4}$ grasses should have been common, the associated grazers, such as Equus and Leptobos, would have consumed $\mathrm{C}_{4}$ grasses as well. In fact, both of these taxa consumed a pure $\mathrm{C}_{3}$ diet. In addition, both fauna and flora show evidence indicating the typical subtropical forest environment of the Jianshi Site [7,27]. However, Early Pleistocene Equus from Yuanmou human sites consumed as much as $70 \% \mathrm{C}_{4}$ grasses in their diets, and lived in an open habitat, as evidenced by their carbon isotope signatures [28]. Thus, all the above data support a subtropical dense forest for the habitat of G. blacki and the associated large mammals.

If Gigantopithecus lived in dense forest habitats, what was their diet? Identification of opal phytoliths bonded to the enamel surface of G. blacki indicates this giant ape had a varied diet of grasses and fruits [29]. Compared with the dental microwear of living anthropoids, G. blacki was intermediate between folivorous forms and hard-object specialists, and was most similar to the predominantly frugivorous Pan troglodytes species [30]. A high frequency of dental caries indicates that the diet of G. blacki was rich in sugar or starch [1,31,32]. The large molars with high crowns and thick enamel indicate an adaptation of strong grinding to hard food.

\subsection{Comparison to extant apes and early hominins}

As the extant hominoids, G. blacki lived in forest habitats, and had a solely $\mathrm{C}_{3}$ biomass diet. This species is different from some early hominins, such as Australopithecus africanus, Paranthropus robustus and Paranthropus boisei in Africa (Figure 2). Stable carbon isotope evidence indicates that A. africanus from Makapansgat [14], Sterkfontein $[15,17]$ and $P$. robustus from Swartkrans $[12,15]$ in South Africa had a mixed diet of $\mathrm{C}_{3}$ and $\mathrm{C}_{4}$ biomass, and $P$. boisei from East Africa consumed a high proportion of $\mathrm{C}_{4}$ biomass (almost $80 \%$ of its diet) $[16,18]$. The data indicate these early hominins could live in open habitats and consume a high proportion of $\mathrm{C}_{4}$ biomass, consisting of tropical/ savannah grasses and certain sedges, and/or animal eating $\mathrm{C}_{4}$ foods. Thus, Leo-Thorp et al. [13] recently suggested that engagement with $\mathrm{C}_{4}$ food resources may mark a fundamental transition in the evolution of hominin lineages in the Pliocene. However, earlier hominins, such as Ardipithecus ramidus, preferred $\mathrm{C}_{3}$ biomass diets and woodland habitats [33].

The present fossil record indicates that G. blacki was distributed widely in South China during the Early Pleistocene (Figure 1), but it was limited to the south of Guangxi Province in the Middle Pleistocene. No fossil record has been discovered for the Late Pleistocene Gigantopithecus until now. It is unclear what may have caused the extinction of this giant ape. Analysis of Pleistocene sporopollen floras in China has shown that there was a significant transformation of vegetation during 1.6-0.8 Ma, and during this period the climate became cold and dry. This environmental change may have been related to the uplift of the Tibetan Plateau [34]. Primates are sensitive to climate and environmental

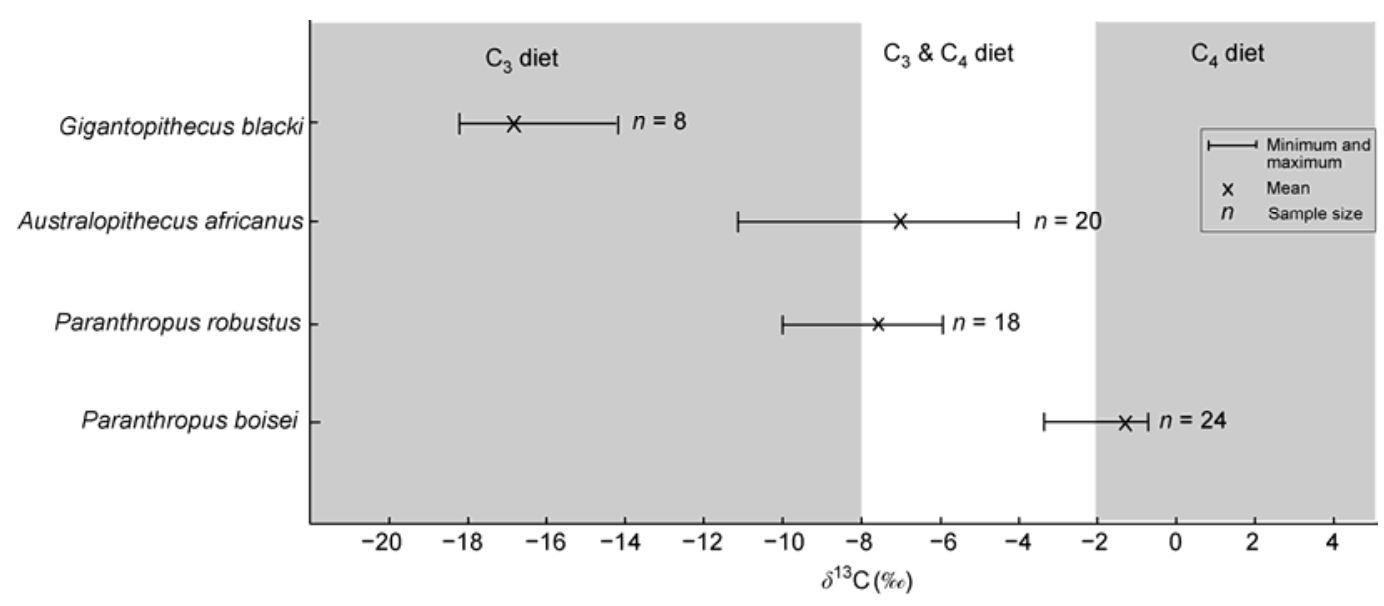

Figure 2 Comparison of diet and enamel stable carbon isotopes $\left(\delta^{13} \mathrm{C}\right)$. 
change, and are likely to be threatened by any situation that involves competition or conflict with humans. The most common and persistent factor that adversely affects populations of wild primates is loss of usable habitat. For example, the only extant great ape in Asia, the orangutan, had been widely distributed in South China during the Pleistocene, and now is only found in Borneo and Sumatra. In 1900, the population of orangutans was estimated to be in excess of 300000 individuals, and in 1997 the total population had dropped to only 27000 individuals [35]. The lesser ape, the black-crested gibbon, is now only found on Hainan Island, in southern and central Yunnan in China and northern Vietnam, although its historic distribution extended to South China [36]. Compared with orangutans and gibbons, $G$. blacki might have been more sensitive to climatic and environmental change as well as habitat contraction from human activity during the Pleistocene. Study on dental development indicates that $G$. blacki had a longer and slower and more delayed growth pattern [37]. This implies a lower reproduction rate, which did not appear to bode well for its population development when the forest habitat became fragmented and deteriorated.

\section{Conclusions}

Stable carbon isotope analyses indicate that $G$. blacki from South China had a diet of pure $\mathrm{C}_{3}$ biomass resources, and lived in dense forest habitats. The diet and habitat of $G$. blacki was significantly different from that of early hominins in Africa, such as Australopithecus and Paranthropus, which could live in open habitats and consume both $\mathrm{C}_{3}$ and $\mathrm{C}_{4}$ resources. Dependence on forest habitat might be an important factor that drove Gigantopithecus extinction when the climate and environment changed dramatically during the Pleistocene.

We are grateful to Prof. Xи Chunhua and Prof. Zheng Shaohua for providing the fossil samples from Longgudong, Jianshi. Special thanks are extended to three reviewers for their comments on the manuscript. This work was supported by the National Natural Science Foundation of China (41072016), the State Key Laboratory of Palaeobiology and Stratigraphy of Nanjing Institute of Geology and Paleontology (103105), the International Cooperation Program of MOST of China (2009DFB20580) and the Specific Basic Research Program of MOST of China (2007FY110200).

1 Woo J K. The mandiles and dentition of Gigantopithecus. Palaeont Sin New Ser D, 1962, 11: 1-94

2 Weidenrich F. Giant early man from Java and South China. Anthrop Papers Amer Mus Nat Hist, 1945, 40: 1-134

3 Weidenrich F. Apes, Giants and Man. Chicago: The University of Chicago Press, 1946. 47-66

4 Frayer D W. Gigantopithecus and its relationship to Australopitheus. Am J Phys Anthropol, 1973, 39: 413-426

5 Pei W Z. The living environment of Chinese primitive men (in Chinese). Paleovertebr Paleoanthropol, 1960, 2: 9-21

6 Hsuu C H, Han K X, Wang L H. Discovery of Gigantopithecus teeth and associated fauna in Western Hubei (in Chinese). Vertebr PalAsiat,
1974, 12: 293-309

7 Zheng S H. Jianshi Hominid Site (in Chinese). Beijing: Science Press, 2004. 1-412

8 Pilbeam D. The Ascent of Man: An Introduction to Human Evolution. New York: Macmillan publishing Co. Inc. 1972. 86-89

9 DeNiro M J, Epstein S. Influence of diet on the distribution of carbon isotopes in animals. Geochim Cosmochim Acta, 1978, 42: 495-506

10 Wang Y, Cerling T. A model of fossil tooth and bone diagenesis: Implications for paleodiet reconstruction from stable isotopes. Palaeogeogr Palaeoclimat Palaeoecol, 1994, 107: 281-289

11 Lee-Thorp J A, Merwe N J Van der. Carbon isotope analysis of fossil bone apatite. South Afr J Sci, 1987, 83: 712-715

12 Lee-Thorp J A, van der Merwe N J, Brain C K. Diet of Australopithecus robustus at Swartkrans from stable carbon isotopic analysis. J Hum Evol, 1994, 27: 361-372

13 Lee-Thorpe J A, Sponheimer M, Passey B H, et al. Stable isotopes in fossil hominin tooth enamel suggest a fundamental dietary shift in the Pliocene. Phil Trans R Soc B, 2010, 365: 3389-3396

14 Sponheimer M, Lee-Thorp J A. Isotope evidence for the diet of an early hominid, Austraolopithecus africanus. Science, 1999, 283: 368-370

15 Sponheimer M, Lee-Thorp J, de Ruiter D, et al. Hominins, sedges, and termites: New carbon isotope data from the Sterkfontein valley and Kruger National Park. J Hum Evol, 2005, 48: 301-312

16 van der Merve N J, Masao F T, Bamford M K. Isotopic evidence for contrasting diets of early hominins Homo habilis and Australopithecus boisei of Tanzania. South Afr J Sci, 2008, 104: 153-155

17 van der Merwe N J, Thackeray J F, Lee-Thorp J A, et al. The carbon isotope ecology and diet of Australopithecus africanus at Sterkfontein, South African. J Hum Evol, 2003, 44: 581-597

18 Cerling T E, Mbua E, Kirera F M, et al. Diet of Paranthropus boisei in the early Pleistocene of East Africa. Proc Natl Acad Sci USA, 2011, 108: 9337-9341

19 Cerling T E, Harris J M, MacFadden B J, et al. Global vegetation change through the Miocene-Pliocene boundary. Nature, 1997, 389: $153-158$

20 Wang Y, Deng T. A 25 m.y. isotopic record of paleodiet and environmental change from fossil mammals and paleosols from the NE margin of the Tibetan Plateau. Earth Planet Sci Lett, 2005, 236: 322-338

21 Gaboardi M, Deng T, Wang Y. Middle Pleistocene climate and habitat change at Zhoukoudian, China, from the carbon and oxygen isotope record from herbivore tooth enamel. Quat Res, 2005, 63: 329-338

22 Gao J. Australopithecine teeth associated with Gigantopithecus (in Chinese). Vert PalAs, 1975, 13: 81-88

23 Cerling T E, Harris J M. Carbon isotope fractionation between diet and bioaptite in ungulate mammals and implications for ecological and paleoecological studies. Oecologia, 1999, 120: 347-363

24 Yin L, Li M. A study on the geographic distribution and ecology of $\mathrm{C}_{4}$ plants in China I. $\mathrm{C}_{4}$ plants distribution in China and their relation with regional climatic condition (in Chinese). Acta Ecol Sin, 1997, 17: 350-363

25 Wang R Z. Natural occurrence and backwater infection of $\mathrm{C}_{4}$ plants in the vegetation of the Yangtze hydropower Three Gorges Project region. Photosynthetica, 2003, 41: 43-48

26 Ehleringer J R, Lin Z F, Field C B, et al. Leaf carbon isotope ratios of plants from a subtropical monsoon forest. Oecologia, 1987, 72: 109_ 114

27 Cheng J, Gao Z. Spore-Pollen records (in Chinese). In: Zheng S H, ed. Jianshi Hominid Site. Beijing: Science Press, 2004. 338-349

28 Biasatti D, Wang Y, Gao F, et al. Paleoecologies and paleoclimates of Late Cenozoic mammals from southwest China: Evidence from stable carbon and oxygen isotopes. J Asian Earth Sci, doi: 10.1016/j. jseaes.2011.04.013

29 Ciochon R L, Piperno D R, Thompson R G. Opal phytoliths found on the teeth of Gigantopithecus blacki: Implications for paleodietary studies. Proc Natl Acad Sci USA, 1990, 87: 8120-8124

30 Daegling D J, Grine F E. Bamboo feeding, dental microwear, and diet of the Pleistocene ape Gigantopithecus blacki. South Afr J Sci, 1994, 90: 527-532 
31 Han K X, Zhao L X. Dental caries of Gigantopithecus blacki from Hubei province of China (in Chinese). Acta Anthrop Sin, 2002, 21: 191-198

32 Zhao L X. Dental caries of Gigantopithecus blacki from Longgudong cave in Jianshi of Hubei (in Chinese). In: Dong W, ed. Proceedings of the Tenth Annual Meeting of the Chinese Society of Vertebrates Paleontology. Beijing: China Ocean Press, 2006. 103-108

33 White T D, Asfaw B, Beyene Y, et al. Ardipithecus ramidus and the paleobiology of early hominids. Science, 2009, 326: 75-86

34 Tong G, Chen Y, Wu X, et al. Pleistocene environmental mega- evolution as indicated by the sporopollen floras in China (in Chinese). J Geomech, 1999, 5: 11-21

35 Shumarker R W, Beck B B. Primates in Question. Washington and London: Smithsonian Books, 2003. 151-156

36 Wang Y X, Jiang X L, Feng Q. Distribution, status and conservation of black-crested gibbon (Hylobates concolor) in China (in Chinese). Acta Anthrop Sin, 2000,19: 139-147

37 Zhao L X. Comprehensive Dental Study on Gigantopithecus blacki (in Chinese). Dissertation for the Doctoral Degree. Beijing: Graduate University of the Chinese Academy of Sciences, 2006

Open Access This article is distributed under the terms of the Creative Commons Attribution License which permits any use, distribution, and reproduction in any medium, provided the original author(s) and source are credited. 